\title{
KEBIJAKAN HUKUM PIDANA DALAM UPAYA PENEGAKAN HUKUM LINGKUNGAN BERDASARKAN PRINSIP PEMBANGUNAN
}

Tarya Sonjaya ${ }^{1}$, Budi Heryanto ${ }^{2}$, Aji Mulyana $^{3}$, M Rendi Aridhayandi ${ }^{4}$

Sekolah Tinggi Hukum Pasundan Sukabumi ${ }^{1}$

Jl. Pasundan, Nyomplong, Kec. Warudoyong, Kota Sukabumi, Jawa Barat 43131 taryasonjaya0262@gmail.com

Sekolah Tinggi Hukum Pasundan Sukabumi ${ }^{2}$

Jl. Pasundan, Nyomplong, Kec. Warudoyong, Kota Sukabumi, Jawa Barat 43131

budiheryanto45@gmail.com

Lembaga Penelitian dan Pengabdian Kepada Masyarakat Universitas Suryakancana ${ }^{3}$ Jl. Pasirgede Raya, Bojongherang, Kec. Cianjur, Kabupaten Cianjur, Jawa Barat 43216 ajimulyana94@gmail.com

\section{Fakultas Hukum Universitas Suryakancana ${ }^{4}$}

Jl. Pasirgede Raya, Bojongherang, Kec. Cianjur, Kabupaten Cianjur, Jawa Barat 43216 mrendiaridhayandi@unsur.ac.id

Submitted : 10/07/2020 Reviewed:22/09/2020 Accepted: 30/09/2020

\begin{abstract}
Criminal law policy to enforce environmental law based on the principles of development requires the protection and management of the environment in the framework of environmentally sustainable development, must pay attention to the level of public awareness and environmental development nationally and globally, and legal instruments relating to the environment. As for a problem in this research is how the law enforcement efforts in society and what are the obstacles that occur in efforts to enforce this environmental criminal law, then this research has the aim of providing input and criticism to policymakers in carrying out environmental law enforcement. The method used in this study uses a normative juridical approach. Criminal law policies in efforts to enforce environmental law are based on the principle of sustainable development that national environmental law and international environmental law have not been able to run optimally in their law enforcement efforts because there is no good synergy and it can be from the inconsistency of policy stakeholders in formulating laws. Law Number 32 of 2009 concerning Environmental Protection and Management. Obstacle factors in carrying out criminal
\end{abstract}


law enforcement efforts are into 4 (four) factors that have not been able to synergize well in efforts to enforce criminal law in the environmental sector.

Keywords: Criminal Law Enforcement; Development; Living environment; Policy.

\begin{abstract}
Abstrak: Kebijakan hukum pidana dalam upaya penegakan hukum lingkungan berdasarkan prinsip pembangunan perlu penyelenggaraan perlindungan dan pengelolaan lingkungan hidup dalam rangka pembangunan berkelanjutan berwawasan lingkungan hidup, harus memperhatikan tingkat kesadaran masyarakat dan perkembangan lingkungan secara nasional dan global serta perangkat hukum yang berkaitan dengan lingkungan hidup. Permasalahan dalam penelitian ini adalah bagaimana upaya penegakan hukum tersebut dalam masyarakat dan apa hambatan yang terjadi dalam upaya penegakan hukum pidana lingkungan ini, maka penelitian ini memiliki tujuan yaitu untuk memberikan masukan dan kritikan kepada pemangku kebijakan dalam menjalankan penegakan hukum lingkungan ini. Metodenya menggunakan metode pendekatan yuridis normatif. Kebijakan hukum pidana dalam upaya penegakan hukum lingkungan berdasarkan prinsip pembangunan berkelanjutan bahwa hukum lingkungan secara nasional, dan hukum lingkungan internasional belum dapat berjalan secara maksimal dalam upaya penegakan hukumnya karena tidak ada sinergi yang baik dan itu dapat dilihat dari ketidakselarasan pemangku kebijakan dalam merumuskan Undang-Undang Nomor 32 Tahun 2009 tentang Perlindungan dan Pengelolaan Lingkungan Hidup. Faktor hambatan dalam menjalankan upaya penegakan hukum pidana terbagi menjadi 4 (empat) faktor yang belum dapat bersinergi dengan baik dalam upaya penegakan hukum pidana di bidang lingkungan
\end{abstract}

Kata Kunci: Kebijakan; Lingkungan Hidup; Pembangunan; Penegakan Hukum Pidana

\section{PENDAHULUAN}

Penegakan hukum lingkungan melalui kebijakan hukum pidana bertujuan untuk memelihara lingkungan tempat tinggal manusia, sehingga dalam pelaksanaannya berorientasi pada prinsip-prinsip pembangunan berkelanjutan. Pembangunan tanpa bersinergi dengan lingkungan akan berakibat tidak terwujudnya tujuan pembangunan. Tercapainya suatu pembangunan merupakan suatu bukti dalam meningkatnya taraf hidup dan kesejahteraan masyarakat, namun seiring dengan kemunduran kualitas sumber daya alam dan terkurasnya sumber daya alam. ${ }^{1}$ Lingkungan yang melampaui ambang batas dan daya tampung lingkungan, akan beresiko terhadap struktur dan fungsi dasar ekosistem yang mengganggu kelangsungan hidup. ${ }^{2}$

Dewasa ini permasalahan hukum lingkungan lebih menitik beratkan pada kebi-

\footnotetext{
Aca Sugandhy, Penataan Ruang Dan Pengelolaan Lingkungan Hidup (Jakarta: PT. Gramedia Pustaka Utama, 1999), 20.

2 Ibid, 21.
} 
jakan pencegahan dibandingkan penindakan (penanggulangan). Karakter hukum lingkungan yang demikian relevan dengan perwujudan pembangunan berkelanjutan, selain itu juga pola kebijaksanaan pembangunan yang tidak mengganggu atau merusak keseimbangan ekosistem merupakan perwujudan dari pembangunan berwawasan lingkungan (Sustainable Development).

Penyelenggaraan perlindungan dan pengelolaan lingkungan hidup dalam rangka pembangunan berkelanjutan berwawasan lingkungan hidup, harus memperhatikan tingkat kesadaran masyarakat dan perkembangan lingkungan secara nasional dan global serta perangkat hukum yang berkaitan dengan lingkungan hidup. Kesadaran dan kehidupan masyarakat dalam kaitannya dengan perlindungan dan pengelolaan lingkungan hidup telah berkembang sedemikian rupa sehingga perlu disempurnakan untuk mencapai tujuan pembangunan berkelanjutan yang berwawasan lingkungan hidup. ${ }^{3}$

Sebagai bentuk perwujudan dari pembangunan berwawasan lingkungan maka awal dari kebijakan penegakan hukum lingkungan hidup diatur dalam Undang-Undang Nomor 4 Tahun 1982 tentang Ketentuan-Ketentuan Pokok Pengelolaan Lingkungan Hidup, dalam kebijakan tersebut memuat prinsip-prinsip pengelolaan lingkungan hidup yang berfungsi memberikan arahan (direction), atau dasar bagi sistem hukum lingkungan nasional dan sistem hukum internasional. Namun, seiring-

\footnotetext{
3 Siswanto Sunarso, Hukum Pidana Lingkungan Hidup Dan Strategi Penyelesaian Sengketa (Jakarta: PT Rineka Cipta, 2005), 1. ; Abdul Charis and Absori, "Penyelesaian Kasus Pencemaran Lingkungan Hidup Di Kawasan Industri Berbasis Peningkatan Sustainable Development Di Kota Semarang" (Universitas Muhammadiyah Surakarta, 2017), 2, http://eprints.ums.ac.id/57582/.
}

nya waktu berjalan dalam jangka waktu 15 tahun terakhir, undang-undang ini pun dicabut karena dianggap kurang sesuai dengan bentuk perwujudan pembangunan berkelanjutan, yang diganti menjadi Undang-Undang Nomor 23 Tahun 1997 tentang Pengelolaan Lingkungan Hidup, dan setelah 12 tahun berjalan diganti lagi oleh Undang-Undang Nomor 32 Tahun 2009 tentang Perlindungan dan Pengelolaan Lingkungan Hidup, yang mana dalam aturan ini lebih menjamin kepastian hukum dan memberikan perlindungan terhadap hak setiap orang untuk mendapatkan lingkungan hidup yang baik dan sehat, melalui penjatuhan sanksi pidana yang cukup berat di dalam undang-undang ini. ${ }^{4}$

Meski undang-undang lingkungan ini sudah melakukan perubahan dari undang-undang lama hingga undang-undang baru dalam menempatkan penegakan hukum pidana dalam undang-undang ini tetap memperhatikan asas ultimum remedium yang mewajibkan penerapan penegakan hukum pidana sebagai upaya terakhir setelah penerapan penegakan hukum administrasi dianggap tidak berhasil. Penerapan asas ultimum remedium ini hanya berlaku bagi tindak pidana formil tertentu, yaitu pemidanaan terhadap pelanggaran baku mutu air limbah, emisi, dan gangguan. Meski Undang-Undang ini memperkenalkan ancaman hukuman minimum di samping maksimum, perluasan alat bukti, pemidanaan bagi pelanggaran baku mutu, keterpaduan penegakan hukum pidana, dan pengaturan tindak

\footnotetext{
${ }^{4}$ So Woong Kim, "Kebijakan Hukum Pidana Dalam Upaya Penegakan Hukum Lingkungan Hidup." Dinamika Hukum 13, no. 3 (2013): 415-427, http:// dinamikahukum.fh.unsoed.ac.id/index.php/JDH/ article/view/247/238. ; Yulanto Araya, "Penegakan Hukum Lingkungan Hidup Di Tengah Pesatnya Pembangunan Nasional." Jurnal Legislasi Indonesia 10, no. 1 (2013): 10,
} 
pidana korporasi. Namun masih belum memberikan suatu ketegasan untuk para pelaku tindak pidana lingkungan.

Pada saat ini jumlah kualitas sumber daya alam di dunia semakin menurun. Hal ini, tentunya akan sangat berpengaruh terhadap manusia yang masih menggantungkan hidupnya terhadap sumber daya alam. Manusia setidaknya akan menggunakan 50\% lebih banyak dari sumber daya alam yang disediakan oleh Bumi, bahkan ini akan terus berlangsung sangat cepat sampai pada tahun 2030, sedangkan Bumi membutuhkan waktu selama 1,5 tahun untuk dapat menghasilkan dan mengisi sumber daya yang telah habis pada waktu satu tahun. Permintaan manusia yang terus meningkat pada sumber daya alam dapat menempatkan tekanan yang sangat luar biasa terhadap keanekaragaman hayati yang tentunya akan mengancam pada wilayah keamanan, kesehatan, kesetaraan, dan kesejahteraan. ${ }^{5}$

Maka dari latar belakang di atas munculah suatu permasalahan, yaitu:

1. Bagaimana kebijakan hukum pidana dalam upaya penegakan hukum lingkungan berdasarkan prinsip pembangunan berkelanjutan?

2. Hambatan dan kendala yang dihadapi dalam rangka Penegakan Hukum Lingkungan terhadap pembangunan nasional dalam jangka panjang di Indonesia?

\section{METODE}

Berdasarkan perumusan masalah dan tujuan penelitian, dapat diidentifikasi bahwa permasalahan pokok dalam penelitian ini ter-

\footnotetext{
5 Anika Ni'matun Nisa and Suharno, "Mewujudkan Pembangunan Berkelanjutan (Studi Kasus Kebakaran Hutan Di Indonesia)." Jurnal Bina Mulia Hukum 4, no. 1 (2020): 294-312, https://jurnal.fh.unpad.ac.id/ index.php/jbmh/article/view/92
}

masuk salah satu kebijakan hukum pidana, khususnya tentang kebijakan hukum pidana dalam upaya penegakan hukum lingkungan berdasarkan prinsip pembangunan berkelanjutan, oleh karena itu pendekatan yang digunakan adalah pendekatan yang berorientasi pada Pendekatan perundang-undangan (statute approach), maka pendekatannya terutama ditempuh lewat pendekatan yuridis normatif yang bertumpu pada data sekunder dan ditunjang dengan pendekatan yuridis normatif.

\section{ANALISIS DAN PEMBAHASAN Kebijakan Hukum Pidana Dalam Upaya Penegakan Hukum Lingkungan Berdasar- kan Prinsip Pembangunan Berkelanjutan}

Hukum lingkungan pada dasarnya merupakan seperangkat aturan hukum (legal rules) yang bertujuan untuk menata lingkungan hidup. Hukum lingkungan pada awalnya bersifat aspek keperdataan, tetapi seiring dengan perkembangan zaman bergeser menjadi hukum administrasi negara, sesuai dengan peningkatan peranan pemerintah dalam turut serta terhadap berbagai segi kehidupan yang berkembang di masyarakat. ${ }^{6}$

Sejak dikeluarkannya UUPPLH 2009 yang menggantikan UU No. 23 Tahun 1997 (selanjutnya disebut UUPPLH 1997), maka fungsi sebagai undang-undang induk umbrella provisions melekat pada UUPPLH 2009. UUPPLH 2009 membawa perubahan yang signifikan dalam pengaturan pengelolaan lingkungan hidup di Indonesia. ${ }^{7}$

Jika dicermati terdapat beberapa perbe-

\footnotetext{
${ }^{6}$ Muhammad Akib, Hukum Lingkungan Perspektif Global Dan Nasional, Revisi (Jakarta: Rajawali Pers, 2014), 91.

7 Edra Satmaidi, "Politik Hukum Pengelolaan Lingkungan Hidup Di Indonesia Setelah Perubahan Undang-Undang Dasar 1945." Jurnal Konstitusi FH Universitas Riau 4, no. 1 (2011): 69-81, https://
} 
daan pengaturan antara UUPPLH 1997 dan UUPPLH 2009. Pertama, UUPPLH 1997 sebagaimana diatur dalam Pasal 41 yang merumuskan tindak pidana sebagai tindakan yang mengakibatkan kerugian (pencemaran dan/atau perusakan lingkungan hidup), sedangkan UUPPLH 2009 sebagaimana diatur dalam Pasal 98, merumuskan tindak pidana yaitu sebagai tindakan yang melewati atau melampaui kapasitas standar baku mutu udara, baku mutu air, baku mutu air laut, atau kriteria baku kerusakan lingkungan hidup. Kedua, UUPPLH 1997 merumuskan pidana dengan pidana maksimum, sedangkan UUPPLH 2009 merumuskan pidana dengan minimum dan maksimum. Ketiga, UUPPLH 2009 mengatur mengenai hal-hal yang tidak diatur dalam UUPPLH 1997 dalam Pasal 100, yaitu diantaranya pemidanaan bagi pelanggaran baku mutu, perluasan alat bukti, keterpaduan penegakan hukum pidana, dan pengaturan tindak pidana korporasi.

Penjelasan UUPPLH 2009 dijelaskan pula mengenai perbedaan mendasar dengan UUPPLH 1997 adalah adanya penguatan yang terdapat dalam undang-undang ini tentang prinsip-prinsip perlindungan dan pengelolaan lingkungan hidup yang didasarkan pada tata kelola pemerintahan yang baik karena dalam setiap proses perumusan dan penerapan instrument pencegahan pencemaran dan/atau kerusakan lingkungan hidup serta penanggulangan dan penegakan hukum, wajib menyerasikan aspek transparansi, partisipasi, akuntabilitas, dan keadilan. ${ }^{8}$

UUPPLH, dalam penjelasan umum, memandang hukum pidana sebagai upaya tera-

media.neliti.com/media/publications/229160-politikhukum-pengelolaan-lingkungan-hid-3247c10d.pdf.

8 Kim, "Kebijakan Hukum Pidana Dalam Upaya Penegakan Hukum Lingkungan Hidup." khir (ultimum remedium) bagi tindak pidana formil tertentu, sementara untuk tindak pidana lainnya yang diatur selain Pasal 100 UUPPLH, tidak berlaku asas ultimum remedium, yang diberlakukan asas premium remedium (mendahulukan pelaksanaan penegakan hukum pidana). Asas ultimum remedium menempatkan penegakan hukum pidana sebagai pilihan hukum yang terakhir. ${ }^{9}$

Ketergantungan penerapan hukum pidana disandarkan pada keadaan sanksi administrasi yang telah dijatuhkan tidak dipatuhi, atau pelanggaran dilakukan lebih dari satu kali. Pengancaman pidananya tidak sama atau lebih ringan dari batas maksimum pidana yang diatur dalam KUHP, dan khususnya dalam Pasal 97 sampai dengan Pasal 115 UUPPLH 2009, sebenarnya tetap dimungkinkan atau diperbolehkan pidana lebih ringan. Hal ini menyebabkan kebingungan dalam penegakan hukum pidana lingkungan hidup, terlebih dalam putusan hakim dalam upaya penjeraan si pelaku (deterrence effect). ${ }^{10}$

Penegakan hukum lingkungan di Indonesia mencakup penataan dan penindakan (compliance and enforcement). ${ }^{11}$ Penegakan hukum lingkungan dalam arti yang luas, yaitu meliputi preventif dan represif. Pengertian preventif sama dengan compliance yang meliputi negosiasi, supervise, penerangan, nasihat), sedangkan represif meliputi penyelidikan, penyidikan sampai pada penerapan sanksi baik administratif maupun pidana. ${ }^{12}$

\footnotetext{
9 Salman Luthan, "Asas Dan Kriteria Kriminalisasi." Jurnal Hukum Ius Quia Iustum 16, no. 1 (2009): 1-17, https://doi.org/10.20885/iustum.vol16.iss1. art1.

${ }^{10}$ Kim, "Kebijakan Hukum Pidana Dalam Upaya Penegakan Hukum Lingkungan Hidup.”

${ }^{11}$ Ibid, 417.

${ }^{12}$ Dyah Adriantini Sintha Dewi, "Konsep Pengelolaan Lingkungan Hidup." Jurnal Fakultas Hukum
} 
Penegakan hukum pengelolaan lingkungan hidup pada saat ini masih sulit dilakukan oleh karena sulitnya pembuktian dan menentukan kriteria baku kerusakan lingkungan. ${ }^{13}$ Upaya penegakan hukum lingkungan hidup melalui hukum pidana adalah bagaimana tiga permasalahan pokok dalam hukum pidana ini dituangkan dalam undang-undang yang sedikit banyak mempunyai peran untuk melakukan rekayasa sosial (social engineering), yaitu yang meliputi perumusan tindak pidana (criminal act), pertanggungjawaban pidana, dan sanksi (sanction) baik pidana maupun tata-tertib. Sesuai dengan tujuan yang tidak hanya sebagai alat ketertiban, hukum lingkungan mengandung pula tujuan pembaharuan masyarakat (social engineering). ${ }^{14}$ Hukum sebagai alat rekayasa sosial sangat penting dalam hukum lingkungan. ${ }^{15}$

Tindak pidana lingkungan hidup diatur dalam Bab XV, yang terdiri dari 23 pasal, dimulai dari Pasal 97 sampai dengan Pasal 120 UUPPLH. Dalam Pasal 97 disebutkan, bahwa tindak pidana sebagaimana dimaksud pada Bab XV itu adalah kejahatan. Dengan demikian, mengenai kejahatan terhadap lingkungan hidup diatur dalam bab tersebut. Di

Universitas Muhammadiyah Magelang 1, no. 1 (2012): 1-19, https://media.neliti.com/media/ publications/23268-ID-konsep-pengelolaanlingkungan-hidup-menuju-kemakmuran-masyarakat. pdf.

${ }^{13}$ Sutrisno, "Politik Hukum Perlindungan Dan Pengelolaan Lingkungan Hidup," Jurnal Hukum Ius Quia Iustum 18, no. 3 (2011): 444-64, https://doi. org/10.20885/iustum.vol18.iss3.art8.

${ }^{14}$ Nyoman Serikat Putra Jaya, Kapita Selekta Hukum Pidana (Semarang: Badan Penerbit UNDIP, 2005).

${ }^{15}$ Helmi, "Hukum Lingkungan Dalam Negara Hukum Kesejahteraan Untuk Mewujudkan Pembangunan Berkelanjutan (Environmental Law in The Welfare State Law Making for Sustainable Development)." Inovatif Jurnal Ilmu Hukum 4, no. 5 (2011): 93-103. samping dalam UUPPLH, kejahatan terhadap lingkungan hidup juga diatur dalam Kitab Undang-Undang Hukum Pidana (KUHP), misalnya dalam Pasal 187, Pasal 188, Pasal 202, Pasal 203, Pasal 502, dan Pasal 503 KUHP. Kejahatan terhadap lingkungan hidup juga terdapat dalam peraturan perundang-undangan di luar KUHP dan diluar UUPLH. ${ }^{16}$

Kejahatan atau tindak pidana lingkungan hidup terdapat dalam berbagai peraturan perundang-undangan selain UUPLH dan KUHP. Oleh karena itu, kecermatan dari para penegak hukum, terutama penyidik, penuntut umum dan hakim sangat diperlukan dalam menemukan peraturan perundang-undangan yang berkaitan dengan tindak pidana lingkungan hidup dalam berbagai macam peraturan perundang-undangan itu. Dengan kata lain, peraturan perundang-undangan mana yang akan digunakan, tergantung pada terhadap sumber daya apa tindak pidana lingkungan hidup itu dilakukan. Perlindungan dan pengelolaan lingkungan hidup pada hakikatnya adalah penerapan prinsip-prinsip ekologi dalam kegiatan manusia terhadap dan atau yang berdimensi lingkungan hidup. ${ }^{17}$

Uraian dalam bagian ini hanya menyoroti secara normatif tindak pidana lingkungan hidup yang sudah diatur dalam RUU KUHP. Analisis lebih mendalam akan diuraikan dalam bagian berikutnya. Ada beberapa catatan atas rumusan tindak pidana lingkungan hidup dalam RUU KUHP. Istilah pencemaran dan perusakan lingkungan dicantumkan dalam Buku I RUU KUHP, dalam Bab tentang Pengertian Istilah. Pasal 192 menentukan bahwa pencemaran lingkungan

\footnotetext{
${ }^{16}$ Ibid, 418."

${ }^{17}$ Muhammad Yunus Wahid, "Prinsip Dan Karakter Hukum Lingkungan," Jurnal Ilmiah Hukum “ISHLAH” 13, no. 2 (2011): 1-23.
} 
hidup adalah masuknya atau dimasukkannya makhluk hidup, zat, energi, dan/atau komponen lain ke dalam lingkungan hidup oleh kegiatan manusia sehingga kualitasnya turun sampai ke tingkat tertentu yang menyebabkan lingkungan hidup tidak dapat berfungsi sesuai dengan peruntukannya. Kemudian, Pasal 200 menentukan bahwa Perusakan lingkungan hidup adalah tindakan yang menimbulkan perubahan langsung atau tidak langsung terhadap sifat fisik dan/ atau hayatinya yang mengakibatkan lingkungan hidup tidak berfungsi lagi dalam menunjang pembangunan berkelanjutan.

Rumusan ini hanya mampu menjerat perbuatan "memasukkan bahan" tetapi belum sampai ke penggolongan jenis bahan berdasarkan akibat yang ditimbulkannya. Potensi akibat yang muncul dari rumusan ini adalah pelaku yang menimbulkan akibat berdampak sangat ringan terhadap nyawa dan/atau kesehatan manusia memiliki ancaman yang sama dengan pelaku yang secara kategori ilmiah menggunakan bahan yang daya rusaknya sangat besar dan meluas baik bagi lingkungan hidup maupun bagi kesehatan dan/atau nyawa manusia.

Menurut Barda Nawawi, jika tidak ada kriteria yang jelas tentang pencemaran sosial budaya maka secara luas dikatakan penyebaran paham komunis, penodaan agama atau mengajak orang tidak menganut agama apa pun menimbulkan pencemaran sosial budaya karena orang menjadi tidak beragama merupakan tindakan pencemaran sosial budaya. ${ }^{18}$

Belum dicantumkannya sanksi bagi kerusakan sosial dan ekonomi akan mencederai keadilan lingkungan, yang mencakup semua aspek, termasuk norma-norma budaya dan aturan-aturan yang berharga, peraturan-per-

${ }^{18}$ Ibid, 421. aturan, kebiasaan-kebiasaan, kebijakan-kebijakan, dan keputusan-keputusan untuk mendukung komunitas-komunitas yang berkelanjutan, di mana manusia dapat berinteraksi dengan kepercayaan tentang lingkungan mereka yang aman, terpelihara, dan produktif. Padahal menurut RUU KUHP Pasal 12, dalam mempertimbangkan hukum yang akan diterapkan, hakim sejauh mungkin mengutamakan keadilan di atas kepastian hukum. ${ }^{19}$

Hukum lingkungan merupakan bidang ilmu yang relatif muda, yang secara global perkembangannya secara pesat baru sejak tiga dasawarsa terakhir. Menurut Munadjat Danusapoetro, tumbuh sejalan bersamaan dengan timbulnya pengertian dan kesadaran untuk melindungi dan memelihara lingkungan hidup. ${ }^{20}$ Tumbuhnya pengertian dan kesadaran umat manusia terhadap lingkungan sebenarnya telah dimulai sejak tahun 1950an. Hal ini sebagai akibat terjadinya berbagai kasus lingkungan beserta akibatnya. Dalam konteks ini terbit buku Rachel Carson yang berjudul "the silent spring" pada tahun 1962. Kesadaran lingkungan ini mencapai puncaknya dengan dilaksanakannya konferensi PBB tentang lingkungan hidup manusia di Stockholm, swedia, dari tanggal 5-16 juni 1972. Hasil-hasil konferensi Stockholm, yaitu Deklarasi Stockholm dan rekomendasi yang merupakan rencana aksi lingkungan (action plan) dan resolusi mengenai lingkungan hidup, telah memberikan landasan dan arahan kepada dunia untuk memberikan pengaturan terhadap masalah lingkungan hidup. Berbagai kesepakatan dan dokumen tersebut telah dijadikan referensi internasional dan sekaligus merupakan tonggak sejarah penting bagi

\footnotetext{
${ }^{19}$ Ibid.

${ }^{20}$ Muhammad Akib, Hukum Lingkungan Perspektif Global Dan Nasional, 179.
} 
perkembangan hukum lingkungan global.

Hukum lingkungan internasional telah berkembang sejak munculnya sebagai kasus lingkungan yang melibatkan negaranegara sebagai pihak perkara, seperti kasus trail smalter (1938) dan kasus Lake Lanoux (1957). Hanya saja, orientasi hukum lingkungan internasional pada masa ini masih berkisar pada upaya-upaya perlindungan hakhak negara pada umumnya, dan belum kepada perlindungan lingkungan. Hukum lingkungan internasional yang berorientasi perlindungan lingkungan, baru berkembang seiring dengan meningkatnya kesadaran lingkungan global sebagaimana diuraikan di atas. ${ }^{21}$

Pada masa sebelum kesadaran lingkungan global lahir (1960-an-1970-an), hukum lingkungan internasional belum merupakan cabang hukum yang berdiri sendiri dan lebih banyak berkembang dalam bentuk hukum kebiasaan internasional (international customary law). Dengan demikian, sangat didominasi oleh karakter hukum internasional umum yang sangat kental dengan sifat international law of coexistence. Hukum lingkungan yang berorientasi kepada lingkungan, mulai tampak sejak tumbuhnya cabang hukum internasional khusus. ${ }^{22}$

Dari uraian di atas dapat disimpulkan, bahwa hukum lingkungan internasional, meskipun telah ada sebelum munculnya kesadaran lingkungan global yang ditandai dengan adanya konferensi Stockholm 1972, dan hukum lingkungan secara nasional bukan merupakan cabang hukum yang berdiri sendiri serta orientasinya belum kepada perlindungan lingkungan secara menyeluruh.

\footnotetext{
${ }^{21}$ Ida Bagus, Hukum Lingkungan Internasional Perspektif Bisnis Internasional (Bandung: Refika Aditama, 2003), 16-17.

${ }^{22}$ Ibid.
}

\section{Hambatan dan Kendala Yang Dihadapi dalam Rangka Penegakan Hukum Ling- kungan Terhadap Pembangunan Nasional Dalam Jangka Panjang Di Indonesia.}

Pembangunan nasional merupakan rangkaian upaya pembangunan yang berkesinambungan yang meliputi seluruh kehidupan masyarakat, bangsa dan negara untuk melaksanakan tugas mewujudkan tujuan nasional yang termaktub dalam Pembukaan Undang-Undang Dasar Negara Republik Indonesia Tahun 1945. ${ }^{23}$

Menurut Jimly Asshiddiqie, bahwa pembangunan berkelanjutan yang berwawasan lingkungan hidup dapat dirumuskan sebagai upaya sadar dan terencana yang memadukan lingkungan, termasuk sumber dayanya ke dalam proses pembangunan yang menjamin kemampuan, kesejahteraan dan mutu hidup generasi masa sekarang dan generasi yang akan datang. ${ }^{24}$

Selanjutnya menurut ketentuan Pasal 1 angka (3) Undang-Undang Nomor 32 Tahun 2009 tentang Perlindungan dan Pengelolaan Lingkungan Hidup, menyebutkan bahwa pembangunan berkelanjutan sebagai upaya sadar dan terencana yang memadukan aspek lingkungan hidup, sosial, dan ekonomi ke dalam strategi pembangunan untuk menjamin keutuhan lingkungan hidup serta keselamatan, kemampuan, kesejahteraan, dan mutu hidup generasi masa kini dan generasi masa depan. Namun pada kenyataannya, masih banyak hambatan dan kendala yang ada

\footnotetext{
${ }^{23}$ Risno Mina, "Desentralisasi Perlindungan Dan Pengelolaan Lingkungan Hidup Sebagai Alternatif Menyelesaikan Permasalahan Lingkungan Hidup," Arena Hukum 9, no. 2 (2016): 149-165, https://doi. org/10.21776/ub.arenahukum.2016.00902.1 .

24 Jimly Asshiddiqie, Green Constitution, Nuansa Hijau Undang-Undang Dasar Negara Republik Indonesia Tahun 1945. (Jakarta: Rajawali Pers, 2010), 135.
} 
dalam kehidupan masyarakat dalam rangka penegakan hukum lingkungan hidup terhadap pembangunan nasional dalam jangka panjang.

Hambatan dan kendala tersebut terletak pada beberapa faktor, yaitu:

1. Faktor kebijakan.

Berbagai kebijakan operasional yang dikeluarkan sering kali tidak konsisten dengan prinsip-prinsip perlindungan dan pengelolaan lingkungan.

2. Faktor kelembagaan.

Fungsi kelembagaan pengelolaan lingkungan bersifat ambivalen atau fungsi kelembagaan yang tidak sesuai dengan kenyataan, dalam melaksanakan wewenang, dan pembagian tugas antara lembaga satu dengan lembaga lainnya.

3. Faktor Peran Pengadilan (Aparat Penegakan Hukum).

Pengadilan sebagai ujung tombak penegakan hukum kurang sensitif terhadap krisis lingkungan masih mengedepankan kebenaran formal dan prosedural dibandingkan dengan penggalian keadilan substansial.

Taverne menyatakan bahwa: "berikanlah kepada saya seorang jaksa yang jujur dan cerdas. Berikanlah saya seorang hakim yang jujur dan cerdas, maka dengan undang-undang yang paling buruk pun, saya akan menghasilkan putusan adil". ${ }^{25}$

Pihak-pihak yang terkait secara langsung dalam proses penegakan hukum lingkungan antara lain: pihak kepolisian, polisi kehutanan (PPNS), kejaksaan, dan hakim. Apabila hendak melihat keberhasilan perlindungan terhadap lingkungan terhadap

\footnotetext{
${ }^{25}$ Achmad Ali, Keterpurukan Hukum Di Indonesia, Penyebab, Dan Solusinya (Jakarta: Ghalia Indonesia, 2002), 68 .
}

lingkungan hidup, sebaiknya para aparat penegak hukum tidak hanya sibuk memperbaiki sistem dan habitat politik dari hukum, tetapi juga menempatkan orangorang dengan visi terhadap perlindungan lingkungan dalam jabatan-jabatan pada pilar-pilar penegakan hukum tersebut. ${ }^{26}$

4. Perjanjian Internasional.

Dengan diratifikasinya perdagangan internasional seperti WTO, FTA (Free Trade Agreement), ASEAN. Ketentuan dalam skema tersebut telah dan berpotensi menciptakan adanya monopoli sumber daya alam (SDA) baik dalam rangka investasi maupun perlindungan kekayaan intelektual, serta pemanfaatan SDA yang cenderung eksploitatif (kontrak karya pertambangan, HPH, dan lain-lain) yang dipastikan akan mengancam kualitas lingkungan serta menimbulkan kerugian bagi masyarakat. Kondisi ini dapat dilihat dari tidak dimasukkannya aspek perlindungan lingkungan menjadi bagian penting untuk mencegah dampak lingkungan yang akan timbul dalam Economic Partnership Agreement (EPA) antara pemerintah Indonesia dengan pemerintah Jepang. Pengaturan tentang perlindungan lingkungan sangat bersifat umum dan tidak holistik yang tidak efektif untuk melindungi lingkungan dan sumber daya alam. ${ }^{27}$

Menurut Soerjono Soekanto hambatan

\footnotetext{
${ }^{26}$ Muhammad Erwin, Hukum Lingkungan Dalam Sistem Perlindungan Dan Pengelolaan Lingkungan Hidup Di Indonesia (Bandung: Refika Aditama, 2015), 169.

${ }^{27}$ Syahrul Machmud, Penegakan Hukum Lingkungan Indonesia (Penegakan Hukum Administrasi, Hukum Perdata, dan Hukum Pidana Menurut UndangUndang No. 32 tahun 2009, (Yogyakarta: Graha Ilmu, 2012), 164.
} 
dalam penegakan hukum lingkungan meliputi beberapa faktor, yaitu:

1. Faktor hukumnya sendiri;

2. Faktor penegak hukum, yang meliputi aparat ataupun lembaga yang membentuk dan menerapkan hukum;

3. Faktor sarana pendukung penegakan hukum;

4. Faktor masyarakat;

5. Faktor kebudayaan, yakni sebagai hasil karya cipta dan rasa yang didasarkan pada manusia dan pergaulan. ${ }^{28}$

Apabila 5 (lima) faktor tersebut tidak sejalan dan tidak ada sinergi antara masyarakat, aparat penegak hukum dan pemangku kebijakan dengan aturan yang ada, maka akan menimbulkan suatu permasalahan yang krusial dalam melaksanakan penegakan hukum lingkungan dan tidak adanya titik temu dalam mencari jalan keluar dalam menangani permasalahan ini.

\section{PENUTUP}

\section{Kesimpulan}

Kebijakan hukum pidana dalam upaya penegakan hukum lingkungan berdasarkan prinsip pembangunan berkelanjutan bahwa hukum lingkungan secara nasional, dan hukum lingkungan internasional belum dapat berjalan secara maksimal dalam upaya penegakan hukumnya karena tidak ada sinergi yang baik dan itu dapat dilihat dari ketidak selarasan pemangku kebijakan dalam merumuskan Undang-Undang Nomor 32 Tahun 2009 tentang Perlindungan dan Pengelolaan Lingkungan Hidup, yang menyebutkan bahwa

\footnotetext{
${ }^{28}$ Rosita Candrakirana, "Penegakan Hukum Lingkungan Dalam Bidang Pengelolaan Sampah Sebagai Perwujudan Prinsip Good Environmental Governance Di Kota Surakarta." Jurnal Yustisia, Vol. 4 No. 3 (2015): 60, https://jurnal.uns.ac.id/yustisia/ article/view/8690/7778
}

objek pelaku tindak pidana lingkungan selain orang perorangan, yaitu korporasi atau badan hukum lainnya yang termasuk ke dalamnya namun dalam Kitab Undang-Undang Hukum Pidana yang termasuk kedalam objek pelaku tindak pidana lingkungan adalah orang atau perorangan. Maka daripada itu perlu sekali perbaikan-perbaikan dalam aturan tersebut.

Beberapa faktor penghambat dalam menjalankan upaya tersebut yaitu faktor kebijakannya itu sendiri, faktor kelembagaan/ aparat penegak hukum, faktor perjanjian internasional, dan faktor masyarakatnya itu sendiri yang belum dapat bersinergi dengan baik dalam upaya penegakan hukum pidana di bidang lingkungan.

\section{Saran}

Saran penulis yang dapat berikan adalah: a. perubahan kebijakan hukum pidana yang sesuai dengan nilai, norma, dan filosofi yang berlaku di masyarakat; dan b. mensinergikan dan sinkronisasi kebijakan hukum pidana yang berlaku dalam masyarakat yang dilakukan oleh aparat penegak hukum, dan pemangku kebijakan dalam penanggulangan kerusakan lingkungan dan mewujudkan pembangunan yang berkelanjutan sesuai dengan wawasan lingkungan hidup.

\section{BIBLIOGRAFI}

\section{Buku}

Akib, Muhammad. Hukum Lingkungan Perspektif Global Dan Nasional. Revisi. Jakarta: Rajawali Pers, 2014.

Ali, Achmad. Keterpurukan Hukum Di Indonesia, Penyebab, Dan Solusinya. Jakarta: Ghalia Indonesia, 2002.

Asshiddiqie, Jimly. Green Constitution, Nuansa Hijau Undang-Undang Dasar Negara Republik Indonesia Tahun 1945. Jakarta: Rajawali Pers, 2010. 
Bagus, Ida. Hukum Lingkungan Internasional Perspektif Bisnis Internasional. Bandung: Refika Aditama, 2003.

Charis, Abdul and Absori. "Penyelesaian Kasus Pencemaran Lingkungan Hidup Di Kawasan Industri Berbasis Peningkatan Sustainable Development Di Kota Semarang." Universitas Muhammadiyah Surakarta, 2017. http://eprints.ums.ac.id/57582/.

Erwin, Muhammad. Hukum Lingkungan Dalam Sistem Perlindungan Dan Pengelolaan Lingkungan Hidup Di Indonesia. Bandung: Refika Aditama, 2015.

Jaya, Nyoman Serikat Putra. Kapita Selekta Hukum Pidana. Semarang: Badan Penerbit UNDIP, 2005.

Machmud, Syahrul. Penegakan Hukum Lingkungan Indonesia (Penegakan Hukum Administrasi, Hukum Perdata, dan Hukum Pidana Menurut Undang-Undang No. 32 tahun 2009. Yogyakarta: Graha Ilmu, 2012.

Sugandhy, Aca. Penataan Ruang Dan Pengelolaan Lingkungan Hidup. Jakarta: PT. Gramedia Pustaka Utama, 1999.

Sunarso, Siswanto. Hukum Pidana Lingkungan Hidup Dan Strategi Penyelesaian Sengketa. Jakarta: PT Rineka Cipta, 2005.

\section{Jurnal}

Araya, Yulanto. "Penegakan Hukum Lingkungan Hidup Di Tengah Pesatnya Pembangunan Nasional." Jurnal Legislasi Indonesia 10, no. 1 (2013): 10.

Candrakirana, Rosita. "Penegakan Hukum Lingkungan Dalam Bidang Pengelolaan Sampah Sebagai Perwujudan Prinsip Good Environmental Governance Di Kota Surakarta." Jurnal Yustisia, Vol. 4 No. 3 (2015): 60. https://jurnal.uns.ac.id/yustisia/article/view/8690/7778

Dewi, Dyah Adriantini Sintha. "Konsep
Pengelolaan Lingkungan Hidup." Jurnal Fakultas Hukum Universitas Muhammadiyah Magelang 1, no. 1 (2012): 1-19. https://media.neliti.com/media/ publications/23268-ID-konsep-pengelolaan-lingkungan-hidup-menuju-kemakmuran-masyarakat.pdf.

Helmi. "Hukum Lingkungan Dalam Negara Hukum Kesejahteraan Untuk Mewujudkan Pembangunan Berkelanjutan (Environmental Law in The Welfare State Law Making for Sustainable Development)." Inovatif Jurnal Ilmu Hukum 4, no. 5 (2011): 93-103.

Kim, So Woong. "Kebijakan Hukum Pidana Dalam Upaya Penegakan Hukum Lingkungan Hidup." Dinamika Hukum 13, no. 3 (2013): 415-427. http://dinamikahukum. fh.unsoed.ac.id/index.php/JDH/article/ view/247/238

Luthan, Salman. "Asas Dan Kriteria Kriminalisasi." Jurnal Hukum Ius Quia Iustum 16, no. 1 (2009): 1-17. https://doi. org/10.20885/iustum.vol16.iss1.art1.

Mina, Risno."DesentralisasiPerlindunganDan Pengelolaan Lingkungan Hidup Sebagai Alternatif Menyelesaikan Permasalahan Lingkungan Hidup." Arena Hukum 9, no. 2 (2016): 149-165. https://doi.org/10.21776/ ub.arenahukum.2016.00902.1.

Nisa, Anika Ni'matun and Suharno. "Mewujudkan Pembangunan Berkelanjutan (Studi Kasus Kebakaran Hutan Di Indonesia)." Jurnal Bina Mulia Hukum 4, no. 1 (2020): 294-312. https://jurnal.fh.unpad.ac.id/index.php/jbmh/article/view/92

Satmaidi, Edra. "Politik Hukum Pengelolaan Lingkungan Hidup Di Indonesia Setelah Perubahan Undang-Undang Dasar 1945." Jurnal Konstitusi 4, no. 1 (2011): 69-81. https://media.neliti.com/media/ 
publications/229160-politik-hukum-pengelolaan-lingkungan-hid-3247c10d.pdf.

Sutrisno. "Politik Hukum Perlindungan Dan Pengelolaan Lingkungan Hidup." Jurnal Hukum Ius Quia Iustum 18, no. 3 (2011): 444-64. https://doi.org/10.20885/iustum. vol18.iss3.art8.

Wahid, Muhammad Yunus. "Prinsip Dan Karakter Hukum Lingkungan." Jurnal Ilmiah Hukum "ISHLAH" 13, no. 2 (2011): $1-23$. 